\title{
COMPLICATIONS AND OUTCOMES OF PREGNANCY IN WOMEN WITH SICKLE CELL ANAEMIA- A STUDY CONDUCTED IN A TERTIARY CARE CENTRE IN NORTH KERALA
}

\author{
Anupama A. Manjula1, Mary Tresa ${ }^{2}$ \\ ${ }^{1}$ Additional Professor, Department of Pathology, Government Medical College, Kozhikode. \\ 2Junior Resident, Department of Pathology, Government Medical College, Kozhikode.
}

ABSTRACT

\section{BACKGROUND}

Many studies have shown that pregnancy in sickle cell anaemia is associated with increased risk of maternal and foetal morbidity and mortality. There is little data on the maternal, foetal and perinatal outcomes of women with sickle cell anaemia in India. No such studies were conducted in Kerala. This study evaluated the various complications and outcomes of pregnancy in women with sickle cell anaemia (HbSS).

\section{MATERIALS AND METHODS}

We carried out a descriptive comparative study of pregnant women in the age group of 15-40 years suffering from Sickle cell anaemia (HbSS) in Government Medical College, Kozhikode. Relevant past history, sickle cell related, obstetric and foetal complications were recorded. All the similar details of controls were collected from medical records. Complete blood count, peripheral smear and HPLC results of cases were analysed. Statistical analysis was done using standard analytical techniques with SPSS version 16.0 for Windows. Quantitative variables were expressed as mean while the qualitative variables were expressed as percentage. The difference and association between study variables were analysed using Chi-square test and $\mathrm{p}$ values $<0.05$ were considered significant.

\section{RESULTS}

A total of 70 women were included in the study. Women with sickle cell anaemia (HbSS) were cases (33). Tribal women without sickle cell anaemia were controls (37). All the cases had anaemia of different grades while only 56.75\% had anaemia among controls. Increased frequency of sickle related complications were noted, especially vaso-occlusive crisis and haemolytic crisis. $87.87 \%$ of cases required blood transfusion. Statistically significant difference in obstetric and foetal complications were not found between cases and controls except for history of previous abortions. The association between HbF levels and occurrence of crisis was also statistically not significant. Neutrophilic leucocytosis was seen in patients with haemolytic crisis and vaso-occlusive crisis without any underlying infection.

\section{CONCLUSION}

This is the first study evaluating the effects of sickle cell anaemia on pregnancy in Kerala. Sickle cell related complications are more frequent during pregnancy. Unlike the previous studies statistical significance regarding obstetric and foetal complications were not found between cases and controls. Early and aggressive management by a multidisciplinary team of gynaecologists, haematologists and paediatricians can reduce the complications and bring good outcome to pregnancy in sickle cell anaemia.

\section{KEYWORDS}

Sickle Cell Anaemia, Pregnancy, Vaso-occlusive Crisis, HbF, Tribals.

HOW TO CITE THIS ARTICLE: Manjula AA, Tresa M. Complications and outcomes of pregnancy in women with sickle cell anaemiaA study conducted in a tertiary care centre in North Kerala. J. Evolution Med. Dent. Sci. 2017;6(64):4634-4639, D0I: 10.14260/Jemds/2017/1002

\section{BACKGROUND}

Sickle cell disease (SCD) is the most prevalent inherited blood disorder worldwide resulting from single DNA mutation within the beta globin gene characterised by the presence of abnormal haemoglobin-HbS. ${ }^{1}$ When deoxygenated HbS gets polymerised and imparts sickle shape to red cells which become less pliable. Repeated episodes of vascular occlusion by sickled red cells result in acute crisis and eventually in end

Financial or Other, Competing Interest: None.

Submission 05-07-2017, Peer Review 28-07-2017,

Acceptance 04-08-2017, Published 10-08-2017.

Corresponding Author:

Dr. Anupama A. Manjula,

Additional Professor,

Department of Pathology,

Government Medical College,

Kozhikode-673008, Kerala.

E-mail: anupamapathology@gmail.com

DOI: $10.14260 /$ jemds $/ 2017 / 1002$

organ damage. Sickle cell disease includes sickle cell anaemia, sickle beta thalassaemia syndromes and haemoglobinopathies in which $\mathrm{HbS}$ is in association with another abnormal haemoglobin. People who inherit two HbS genes develop sickle cell anaemia (HbSS) and those with one normal and one HbS gene become sickle cell trait (HbAS). Sickle cell anaemia is very common in tribal populations. In India the disease is found in variable proportions among the tribals of Andhra Pradesh, Orissa, Maharashtra, Madhya Pradesh, Tamilnadu, Rajasthan, Gujarat, Karnataka and Kerala. In Kerala, sickle cell anaemia is prevalent in Wayanad district and the Attappady block of Palakkad district. Prevalence of sickle cell anaemia among tribals in Wayanad is about $0.31 \%$ and that of sickle cell trait is about $4.33 \%$. The survival of patients with sickle cell anaemia seems to be higher in Kerala as compared to other states. ${ }^{2}$ Many studies have shown that pregnancy in sickle cell anaemia is associated with increased risk of maternal and foetal morbidity and mortality. 3,4,5,6 
There is little data on the maternal, foetal and perinatal outcomes of women with sickle cell anaemia in India. No such studies were conducted in Kerala.

\section{MATERIALS AND METHODS}

We carried out a descriptive comparative study of pregnant women in the age group of 15-40 years suffering from Sickle cell anaemia (HbSS) in Government Medical College, Kozhikode from November 2014 to October 2016. The patients were included in the study after getting informed consent in native language from them. Relevant clinical information like age, gravidity, parity, treatment for infertility, previous abortions and obstetric history were collected and recorded by direct interview with the patients. Investigations like complete blood count, liver function test, renal function test, peripheral smear examination and automated high-performance liquid chromatography (HPLC) were done for each case. Maternal complications recorded were anaemia, different types of crisis, acute chest syndrome, pulmonary thromboembolism, pulmonary hypertension, pregnancy-induced hypertension/preeclampsia, eclampsia and maternal death. Mode of delivery was also recorded. Foetal complications recorded were preterm delivery, intrauterine growth restriction (IUGR), low birth weight babies (LBW), intrauterine death, stillbirth and neonatal death. The controls selected for comparison were tribal women without sickle cell anaemia admitted in the same institution. All the similar details of controls were collected from medical records.

\section{Statistical Analysis}

Data was entered according to the variables onto spreadsheets of Microsoft Office Excel 97 - 03 and the variables were analysed using standard analytical techniques with SPSS version 16.0 for Windows. Quantitative variables were expressed as mean while the qualitative variables were expressed as percentage. The difference and association between study variables were analysed using Chi-square test and $p$ values $<0.05$ were considered significant.

\section{RESULTS}

A total of 70 women were included in the study. Women with sickle cell anaemia (HbSS) were cases (33). Tribal women without sickle cell anaemia were controls (37). Out of 33 cases, 28 were tribals $(74.85 \%)$ and 5 (15.15\%) were belonging to Chetti community. Majority were from Wayanad District. Majority of the cases included in this study belonged to the Paniya community (64\%).

17 patients were primigravidae, 2 of them became aware of their disease only during pregnancy. The mean age of cases and controls were 25.58 years and 24.73 years respectively.

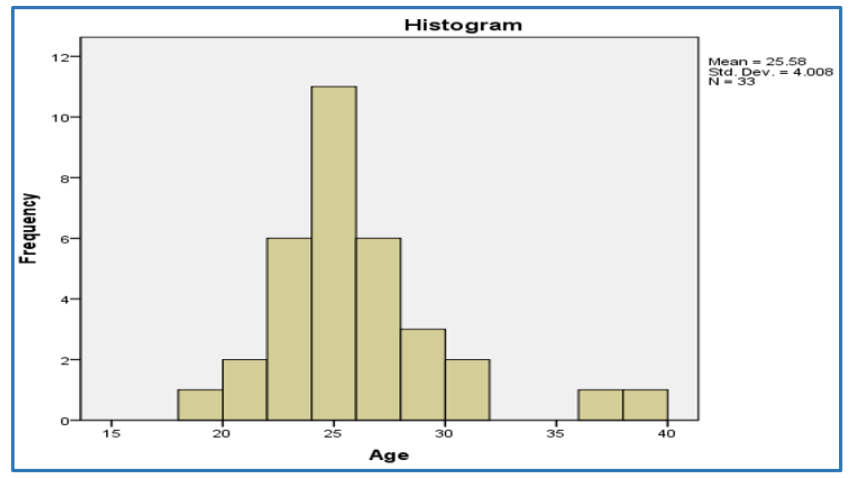

Figure 1. Age Wise Distribution of Cases

22 patients were on hydroxyurea (HU) before pregnancy, but stopped after confirmation of pregnancy. Only one patient continued HU throughout the pregnancy.

\section{Evaluation of Anaemia}

All the cases in this study had anaemia. Based on the ICMR categories of anaemia, 3 patients had mild anaemia (Hb-10$10.9 \mathrm{~g} / \mathrm{dL}), 21$ had moderate anaemia $(7-9.9 \mathrm{~g} / \mathrm{dL}), 5 \mathrm{had}$ severe anaemia (4-6.9 g/dL) and 3 had very severe anaemia $(<4 \mathrm{~g} / \mathrm{dL}) .12$ patients had microcytic hypochromic anaemia, 3 had macrocytic anaemia and 17 had normocytic normochromic anaemia. (For one patient who was brought dead, blood investigations were not done). Out of 37 controls, only 21 had anaemia. 5 had mild, 12 had moderate and 4 had severe anaemia. Very severe anaemia was not detected in controls.

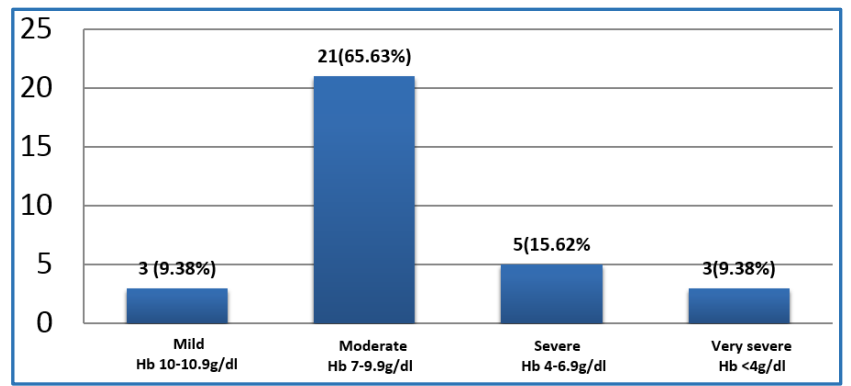

Figure 2. Cases with Different Grades of Anaemia

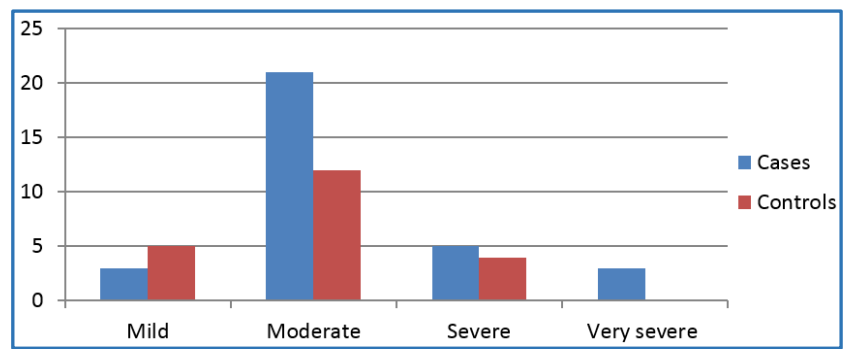

Figure 3. Comparison of Severity of Anaemia in Cases and Controls

Sickle Cell Anaemia related Maternal Complications in Cases

30 patients had any one type of crisis during pregnancy. 17 had both haemolytic and vaso-occlusive crisis. 3 cases had all the three types of crisis (haemolytic, vaso-occlusive and splenic crisis). Many had more than one episode of crisis, majority was in the third trimester. 24 cases $(72.72 \%)$ had vaso-occlusive crisis (VOC) and 23 had haemolytic crisis (69.69\%). The main complaint of those with VOC was 
intractable pain in the extremities and half of them needed opioids in addition to blood transfusions and IV fluids. Only 3 patients did not have crisis throughout pregnancy. 5 cases (15.15\%) had acute chest syndrome. 6 (18.20\%) had congestive cardiac failure, $4(12.12 \%)$ had pulmonary hypertension and 3 (9.09\%) had pulmonary embolism with deep vein thrombosis.

\section{Obstetric Complications}

10 cases had abortions in the past (30.30\%) and 5 of them had more than 2 abortions. Among the controls, 4 had previous abortions (10.81\%). 4 cases (12.12\%) had pregnancy-induced hypertension/preeclampsia and 2 $(6.06 \%)$ had eclampsia compared to $6(16.22 \%)$ and 2 $(5.41 \%)$ respectively among controls.

\section{Maternal Death}

There were 2 maternal deaths among cases (6.06\%) and none among the controls. One case who died had acute Chest syndrome, crisis, ante-partum eclampsia, massive pulmonary embolism and congestive cardiac failure. She was 32 weeks pregnant and had not taken regular antenatal checkups. She had been on hydroxyurea only one year before confirmation of pregnancy and then stopped.

The other patient was brought dead to our institution at 26 weeks of gestation with twin pregnancy. She was not on regular antenatal checkups and has not taken HU or folic acid. Her autopsy report showed liver, spleen, brain, kidney and adrenals congested with irreversibly sickled RBCS and bone marrow showed erythroid hyperplasia with megaloblastic change and histiocytes showing haemophagocytosis.

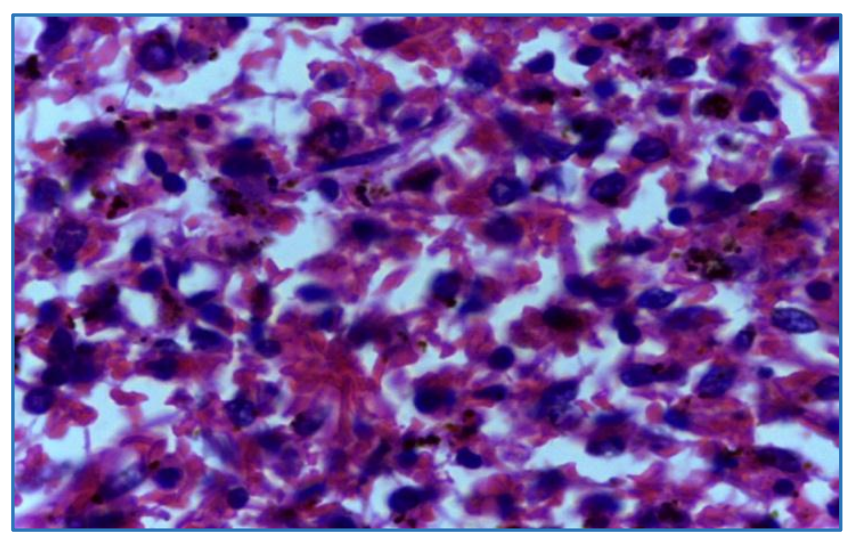

Figure 4. Microscopy H\&E, X200. Section from Spleen of the Case who was brought Dead

\section{Mode of delivery}

The mode of delivery was caesarean section in 9 cases (27.27\%) and 12 controls (32.43\%).

\section{Blood Transfusions}

29 cases $(87.87 \%)$ required blood transfusion during pregnancy, some were given multiple transfusions and 3 of them had more than eight transfusions.

\section{Foetal Complications}

The main complications were intrauterine growth restriction (IUGR), low birth weight (LBW) babies (weight $<2500 \mathrm{~g}$ ), preterm delivery and intrauterine death (IUD). There were $18(54.54 \%)$ low birth weight (LBW) babies and 14 babies
(42.42\%) had features of IUGR compared to 22 LBW babies (59.46) and 13 IUGR (35.13) in controls. 9 deliveries $(27.27 \%)$ were preterm ( $<37$ weeks) in cases and 7 (18.92) in controls. There were $2(6.06 \%)$ intrauterine deaths in cases and 3 (8.11) in controls. One IUD occurred while the mother had acute chest syndrome, CCF, thromboembolism and pulmonary hypertension. The other IUD occurred while the mother was suffering from haemolytic crisis. No congenital anomalies were detected.

\begin{tabular}{|c|c|c|c|}
\hline & $\begin{array}{c}\text { Cases } \\
\text { (Sickle cell } \\
\text { anaemia } \\
\text { Hb SS) n (\%) }\end{array}$ & $\begin{array}{c}\text { Controls } \\
\text { (Tribals- } \\
\text { without sickle } \\
\text { cell anaemia) } \\
\text { n (\%) }\end{array}$ & $\begin{array}{c}\text { p } \\
\text { value }\end{array}$ \\
\hline No. of Patients & 33 & 37 & \\
\hline Mean Age (Years) & 25.58 & 24.73 & \\
\hline Primigravida & $17(51.5)$ & $15(40.54)$ & 0.358 \\
\hline Multigravida & $16(48.5)$ & $22(59.46)$ & 0.358 \\
\hline $\begin{array}{c}\text { Severe Anaemia } \\
\text { Hb<7 g/dL }\end{array}$ & $4(25)$ & $4(10.81)$ & 0.137 \\
\hline Previous abortions & $10(30.30)$ & $4(10.81)$ & 0.042 \\
\hline PIH/preeclampsia & $4(12.12)$ & $6(16.22)$ & 0.625 \\
\hline Eclampsia & $2(6.06)$ & $2(5.41)$ & 0.906 \\
\hline Preterm delivery & $9(27.27)$ & $7(18.92)$ & 0.406 \\
\hline Caesarean Sections & $9(27.27)$ & $12(32.43)$ & 0.638 \\
\hline $\begin{array}{c}\text { Low birth } \\
\text { weight babies }\end{array}$ & $18(54.54)$ & $22(59.46)$ & 0.678 \\
\hline IUGR & $14(42.42)$ & $13(35.13)$ & 0.532 \\
\hline IUD (\%) & $2(6.06)$ & $3(8.11)$ & 0.741 \\
\hline NND (\%) & Nil & $1(2.70)$ & 0.341 \\
\hline Maternal death (\%) & $2(6.06)$ & Nil & 0.129 \\
\hline VOC & $23(69.69)$ & NA & \\
\hline Haemolytic crisis & $23(69.69)$ & NA & \\
\hline Splenic crisis & $3(9.09)$ & NA & \\
\hline $\begin{array}{c}\text { Acute chest } \\
\text { syndrome }\end{array}$ & $5(15.15)$ & NA & \\
\hline $\begin{array}{c}\text { Pulmonary } \\
\text { Thromboembolism }\end{array}$ & $3(9.09)$ & NA & \\
\hline Pulmonary HTN & $4(12.12)$ & NA & \\
\hline $\begin{array}{c}\text { Congestive } \\
\text { cardiac failure }\end{array}$ & $6(18.20)$ & NA $)$ & \\
\hline Comparison of Maternal and & \\
\hline
\end{tabular}

\section{Peripheral Smear Examination}

Peripheral smear examination of all the cases were done except the one who was brought dead.

In addition to the sickled RBCs, 13 had normoblasts and polychromasia, 15 had neutrophilic leucocytosis and 12 had thrombocytopenia. Neutrophilic leucocytosis was seen in patients with haemolytic crisis and vaso-occlusive crisis that too without any underlying infection.

\section{HPLC Findings}

On analysing the HPLC results of 32 patients (HPLC result was not available for one patient who was brought dead), the percentage of $\mathrm{HbS}$ ranged between 28.6 and 78.3. 4 patients had $\mathrm{HbF}$ between 0 and 10\%, 17 had $\mathrm{HbF}$ between 10 and $20 \%$ and $11 \mathrm{had} \mathrm{HbF}>20 \%$. 


\begin{tabular}{|c|c|c|c|c|c|}
\hline & \multicolumn{2}{|c|}{ Crisis } & \multirow{2}{*}{$\begin{array}{c}\text { p } \\
\text { value }\end{array}$} \\
\hline & & & No & Yes & \\
\hline \multirow{6}{*}{$\mathbf{H b F}$} & \multirow{2}{*}{$0-10 \%$} & No. of patients & Nil & 4 & \multirow{6}{*}{0.636} \\
\hline & & $\%$ & - & $100 \%$ & \\
\hline & \multirow{2}{*}{$10-20 \%$} & No. of patients & 2 & 15 & \\
\hline & & $\%$ & $11.78 \%$ & $88.24 \%$ & \\
\hline & \multirow{2}{*}{$>20 \%$} & No. of patients & 2 & 9 & \\
\hline & & $\%$ & $18.18 \%$ & $81.81 \%$ & \\
\hline \multicolumn{6}{|c|}{$\begin{array}{l}\text { Table 2. Association between Percentage } \\
\text { of HbF and the Occurrence of Crisis }\end{array}$} \\
\hline
\end{tabular}

\section{DISCUSSION}

It is well established that women with SCD have an increased risk of maternal and foetal morbidity and mortality during pregnancy compared to healthy women.3,4,5,6 We report for the first time the complications and outcomes of pregnancy in women with Sickle cell anaemia (SCA- HbSS) in Kerala. As $75 \%$ of the SCA patients were tribals, the maternal and foetal complications noted in women with SCA were compared with that of the tribal women without sickle cell anaemia delivered in our institution.

WHO defines anaemia in pregnancy as haemoglobin concentration of less than $11 \mathrm{~g} / \mathrm{dL}$. ICMR describes four grades of anaemia depending upon the haemoglobin levels. Mild anaemia- $\mathrm{Hb} 10$ to 10.9 , modearate -7 to 9.9 , severe- 4 to 6.9 and very severe $<4 \mathrm{~g} / \mathrm{dL} .^{7}$ Majority of the patients with sickle cell disease (SCD) have some degree of baseline anaemia due to ongoing haemolysis. ${ }^{8}$ In this study also all the cases had anaemia. In the controls, only $56.75 \%$ had anaemia.

\begin{tabular}{|c|c|c|c|}
\hline & $\begin{array}{c}\text { Fouedjio } \\
\text { JH et al }^{4} \\
(2016, \\
\text { Cameroon) }\end{array}$ & $\begin{array}{c}\text { Desai G } \\
\text { et al }{ }^{5} \\
\text { (2017, } \\
\text { Gujarat) }\end{array}$ & $\begin{array}{l}\text { Current } \\
\text { Study }\end{array}$ \\
\hline No of patients with SCA & 32 & 131 & 33 \\
\hline Mean age (years) & 36.1 & & 25.58 \\
\hline Primigravida (\%) & & & 51.5 \\
\hline Multigravida (\%) & & & 48.5 \\
\hline $\begin{array}{l}\text { Severe anaemia } \\
\mathrm{Hb}<7 \mathrm{~g} / \mathrm{dL}(\%)\end{array}$ & 37.5 & 22.1 & 25 \\
\hline Previous abortions (\%) & 37.5 & & 30.30 \\
\hline PIH/preeclampsia (\%) & & 6.1 & 12.12 \\
\hline Eclampsia (\%) & 15.6 & 2.3 & 6.06 \\
\hline Sickle cell crisis (\%) & 40.6 & 47.3 & 87.87 \\
\hline Ac chest syndrome $(\%)$ & - & - & 15.15 \\
\hline $\begin{array}{c}\text { Pulmonary } \\
\text { hypertension (\%) }\end{array}$ & - & - & 12.12 \\
\hline $\begin{array}{c}\text { Pulmonary } \\
\text { embolism }(\%)\end{array}$ & - & - & 9.09 \\
\hline $\begin{array}{c}\text { Congestive } \\
\text { cardiac failure (\%) }\end{array}$ & - & - & 18.20 \\
\hline Preterm deliveries (\%) & 40.6 & 45 & 27.27 \\
\hline Caesarean sections \% & 71.9 & 17.6 & 27.27 \\
\hline $\begin{array}{c}\text { Low birth } \\
\text { weight babies (\%) }\end{array}$ & 28.1 & 70.2 & 54.54 \\
\hline IUGR (\%) & 25 & 2.3 & 42.42 \\
\hline IUD (\%) & 12.5 & & 6.06 \\
\hline Stillbirth (\%) & 6.3 & 9.9 & Nil \\
\hline Maternal death (\%) & 3.1 & Nil & 6.06 \\
\hline
\end{tabular}

Sickle cell crisis (both vaso-occlusive (VOC) and haemolytic crises) was the most frequent maternal complication in our series, accounting for $90.91 \%$ of cases. $72.73 \%$ of cases had VOC. This rate of crisis is much more than the rates of $40.6 \%$ and $47.3 \%$ reported by Fouedjio JH et al from Cameroon and Desai $G$ et al from Gujarat respectively.4,5 A population-based study carried out in Wayanad reported the occurrence of VOC in $43.5 \%$ of sickle cell anaemia patients. ${ }^{2} 15.2 \%$ of our patients had acute chest syndrome. But none were reported in the previous two studies. Our cases had pulmonary embolism (9.09\%), pulmonary hypertension (12.12\%) and congestive cardiac failure $(18.20 \%)$. But none were reported from the previous two studies.

The rate of severe anaemia $(\mathrm{Hb}<7 \mathrm{~g} / \mathrm{dL})$ seems to be higher in cases $(25 \%)$ than in controls $(10.81 \%)$. But the difference is not statistically significant ( $p$ value 0.137 ). But it is comparable with the rate of $22.1 \%$ reported by Desai G et al and lower than that reported by Fouedjio JH et al (37.5\%). The rates in cases and controls are very high compared to the rate of severe anaemia complicating pregnancy in our institution $(0.3 \%)$. The rate of previous abortions $(30.30 \%)$ is significantly higher than that in controls $(10.81 \%)$ ( $p$ value 0.042 ) and is lower than that reported by Fouedjio JH et al. The rate of maternal death in cases $(6.06 \%)$ and that reported by Fouedjio JH et al (3.1\%) are very high compared to the maternal mortality rate in India $(0.174 \%)$. No maternal deaths were reported in the study by Desai G et al. ${ }^{4,5}$ No maternal deaths occurred in the control group but the difference is not statistically significant ( $p$ value 0.129 ). The maternal death rate in our institution was $0.12 \%$.

The rate of eclampsia $(6.06 \%)$ is comparable with that of the controls $(5.41 \%)$. It is lower than that reported by Fouedjio JH et al (15.6\%) but higher than that reported by Desai G et al (2.3\%). The rate of eclampsia in our institution was $0.21 \%$ while in a study conducted by Nobis PN et al, the average incidence in India is $1.5 \% .{ }^{9}$ The rate of pregnancyinduced hypertension (PIH)/preeclampsia was higher in the control group (16.22\% vs. $12.12 \%)$. Most of the patients in control group were referred from periphery due to severe $\mathrm{PIH} /$ severe preeclampsia. The rate is higher than that reported by Desai G et al (6.1\%). In our institution, the rate of $\mathrm{PIH} /$ preeclampsia was $9.72 \%$ and the incidence in India is 8 to $10 \% .^{10}$ The rate of caesarean sections is also higher in the control group than the cases $(32.43 \%$ vs. $27.27 \%)$. The rate in our institution was higher than that of the control $(36.38 \%)$. This is because most of the patients were referred to our institution due to various complications. A very high rate was reported by Fouedjio JH et al (71.9\%). But the rate reported by Desai G et al (17.6\%) is lower than ours. ${ }^{4,5}$

Rate of foetal complications like preterm deliveries and IUGR seem to be higher in SCA cases than in the controls. But the differences were not statistically significant $(p$ value 0.406 and 0.532 ). The rate of preterm deliveries reported from the two previous studies ( $40.6 \%$ and $45 \%$ ) were higher than ours $(27.27 \%)$. The rates in controls and in the institution, were $18.92 \%$ and $15.31 \%$ respectively. The rate of IUGR reported from the two previous studies $(25 \%$ and $2.3 \%$ ) are very much lower than that of our cases $(42.4 \%)$ and controls (35.13\%). In our institution, the rate of IUGR is 
$20.78 \%$. The rate of low birth weight babies (54.5\%) is lower than that reported by Desai G et al (70.2\%) but higher than that reported by Fouedjio $\mathrm{JH}$ et al (28.1\%). The rate in controls $(59.45 \%)$ is higher than that of cases in our study. The rate of IUD is lower in cases $(6.06 \%)$ than in controls $(8.11 \%)$ and is very much lower than that reported by Fouedjio JH et al (12.5\%). The rate of IUD in our institution is $2.07 \%$. There were no stillbirths or neonatal deaths among cases in this study while the other two studies reported stillbirths. ${ }^{4,5}$

\section{Peripheral Smear Examination}

In addition to the sickled RBCs, 13 had normoblasts and polychromasia, 15 had neutrophilic leucocytosis and 12 had thrombocytopenia. Neutrophilic leucocytosis was seen in patients with haemolytic crisis and vaso-occlusive crisis that too without any underlying infection. Neutrophilia is a wellrecognised complication of sickle cell disease (SCD) and is a risk factor for increased disease severity and early death. Increased neutrophil activation, adhesion and oxidant production have been reported in SCD. Chronic biochemical and functional changes of neutrophils in SCD contribute to disease pathology and are amplified during vaso-occlusive crisis. ${ }^{11}$ So detection of asymptomatic neutrophilia may help to predict the occurrence of VOC.

\section{HbF Levels and Crisis}

Many studies have shown that higher HbF levels are associated with a reduced rate of acute painful episodes, fewer leg ulcers, less osteonecrosis, less frequent acute chest syndromes, and reduced disease severity. But the association is weak or absent with priapism, stroke and silent cerebral infarction, systemic blood pressure, and tricuspid regurgitant velocity. ${ }^{12}$ The manifestations of SCD in Indian population are milder than those seen in African populations, predominantly because of high $\mathrm{HbF}$ levels. ${ }^{1}$

In this study also it is seen that the percentage of cases who had crisis decreases with increasing levels of $\mathrm{HbF}$. But statistically significant association was not found between $\mathrm{HbF}$ levels and the occurrence of crisis ( $p$ value 0.636 ).

\section{Use of Hydroxyurea (HU)}

Hydroxyurea, a myelosuppressive agent, has been shown to potentially increase the level of $\mathrm{HbF}$ and is currently the most effective disease-modifying therapy for both adults and children with SCA. ${ }^{13}$ Hydroxyurea is the only effective drug proven to reduce the frequency of vaso-occlusive crisis. It raises the level of $\mathrm{HbF}$ and the haemoglobin level. It usually decreases the rates of vaso-occlusive crisis and acute chest syndrome and the need for blood transfusions by $50 \%$ in adults. ${ }^{14}$ In this study, 21 patients were on hydroxyurea before pregnancy. Only 1 patient continued HU throughout pregnancy and she had only one episode of VOC that too in the third trimester and no congenital anomalies were detected in the baby. 11 patients had never been on $\mathrm{HU}$.

\section{CONCLUSIONS}

1. This is the first study evaluating the effects of sickle cell anaemia on pregnancy in Kerala.
2. Sickle cell related complications are more frequent during pregnancy.

3. Unlike the previous studies, statistically significant differences in obstetric and foetal complications were not found between cases and controls.

4. The high incidence of obstetric and foetal complications in controls needs further evaluation. Ours being a tertiary care referral hospital, most of the patients admitted here are expected to have complications.

5. Our study suggests that women with severe sickle cell anaemia, even if they have a bad obstetric history, can carry their pregnancy to term, without major obstetric and foetal complications, through early and aggressive management by a multidisciplinary team of gynaecologists, haematologists and paediatricians.

\section{REFERENCES}

[1] Tewari S, Rees D. Morbidity pattern of sickle cell disease in India: a single centre perspective. The Indian Journal of Medical Research 2013;138(3):28890.

[2] Feroze M, Aravindan KP. Sickle cell disease in Wayanad, Kerala: gene frequencies and disease characteristics. The National Medical Journal of India 2001;14(5):267-70.

[3] Wilson NO, Ceesay FK, Hibbert JM, et al. Pregnancy outcomes among patients with sickle cell disease at Korle-Bu teaching hospital, Accra, Ghana: retrospective cohort study. The American Journal of Tropical Medicine and Hygiene 2012;86(6):936-42.

[4] Fouedjio JH, Fouelifack FY, Fouogue JT, et al. Maternal and foetal outcomes of pregnancy with homozygous sickle cell disease: a case - control study at the Yaounde Central Hospital, Cameroon. Women Heal Int 2016;2(1):113.

[5] Desai G, Anand A, Shah P, et al. Sickle cell disease and pregnancy outcomes: a study of the community-based hospital in a tribal block of Gujarat, India. Journal of Health Population and Nutrition 2017;36(1):3.

[6] Villers MS, Jamison MG, De Castro LM, et al. Morbidity associated with sickle cell disease in pregnancy. American Journal of Obstetrics and Gynecology 2008;199(2):125.e1-5.

[7] Sharma JB, Shankar M. Anaemia in pregnancy. Differential Diagnosis in Obstetrics and Gynaecology: An AZ 2008;31:19.

[8] Ballas SK, Kesen MR, Goldberg MF, et al. Beyond the definitions of the phenotypic complications of sickle cell disease: an update on management. The Scientific World Journal 2012;2012:949535.

[9] Nobis PN, Hajong A. Eclampsia in India through the decades. The Journal of Obstetrics and Gynecology of India 2016;66(Suppl 1):172-6.

[10] National Health Portal of India. https://nhp.gov.in/disease/gynaecology-andobstetrics/preeclampsia. 2016. 
[11] Hanson MS, Wandersee NJ, Hessner MJ, et al. Neutrophil activation in sickle cell disease: biochemical and functional changes at baseline and during acute vaso-occlusive crises. Free Radical Biology and Medicine 2013;65:S71.

[12] Steinberg MH, Sebastiani P. Genetic modifiers of sickle cell disease. American Journal of Hematology 2012;87(8):795-803.
[13] McGann PT, Nero AC, Ware RE. Current management of sickle cell anemia. Cold Spring Harbor Perspectives in Medicine 2013;3(8):a011817.

[14] Agrawal RK, Patel RK, Shah V. Hydroxyurea in sickle cell disease: drug review. Indian Journal of Hematology \& Blood Transfusion 2014;30(2):91-6. 